\title{
Rancangan Aplikasi Surat Tugas Dan Surat Perintah Perjalanan Dinas Berbasis Website
}

\author{
Yosi Mardoni ${ }^{1}$, Erman Arif ${ }^{2}$ \\ email: yosimardoni@ecampus.ut.ac.id ${ }^{1}$,erman.arif@ecampus.ut.ac.id ${ }^{2}$ \\ ${ }^{1,2}$ Universitas Terbuka
}

\begin{abstract}
Abstrak
Surat Tugas dan Surat Perintah Perjalanan Dinas (SPPD) merupakan surat dinas yang biasa digunakan untuk keperluan pekerjaan formal di lingkungan pegawai negeri sipil (ASN). Perlunya struktur penugasan dan SPPD ketika ASN diperintahkan untuk melaksanakan tugas tertentu atau melakukan penugasan ke daerah tertentu atau instansi lain. Perjalanan dinas dapat dilakukan di dalam kabupaten / kota maupun di luar wilayah kabupaten / kota. Studi ini bertujuan untuk membuat surat rancangan aplikasi surat tugas yang dapat digunakan oleh seluruh dosen dan tenaga kependidikan di lingkungan Universitas Terbuka. Universitas Terbuka yang merupakan salah satu lembaga negara saat ini menggunakan proses pembuatan tugas dan pesanan perjalanan dinas (SPPD) secara manual dengan menggunakan spreadsheet excel. Proses pembuatan manual yang dilakukan pada surat tugas dan SPPD menyebabkan banyak masalah. Atas dasar lambatnya proses tersebut maka peneliti menilai perlu dikembangkan aplikasi berbasis website untuk penulisan surat tugas dan SPPD khususnya di lingkungan Universitas Terbuka. Metode yang digunakan untuk membangun sistem informasi aplikasi pembuatan surat tugas dan SPPD ini yaitu menggunakan metode Waterfall dengan 5 tahapan yang harus dilalui yaitu: Analisis, Desain, Implementasi, Testing dan Pemeliharaan.
\end{abstract}

Kata kunci : rancangan aplikasi website, Surat tugas dan SPPD, waterfall

\section{Pendahuluan}

Surat Perintah Perjalanan Dinas (SPPD) merupakan Surat Dinas digunakan untuk kepentingan pekerjaan formal seperti instansi, dinas dan tugas kantor, dalam kedinasan ketika seorang Pegawai Negeri Sipil (PNS) diperintahkan untuk melakukan tugas tertentu atau diperintahkan untuk melakukan tugas ke Daerah maupun instansi lainnya. Perjalanan dinas dapat dilakukan didalam daerah kabupaten/kota maupun luar daerah kabupaten/kota ${ }^{[1]}$.

Di Universitas Terbuka saat ini proses pembuatan surat tugas dan Surat Perintah Perjalanan Dinas (SPPD) masih dilakukan secara manual menggunakan spreadsheet excel, hal tersebut membuat rentan kesalahan misalnya pada perhitungan nominatif, atau bisa juga terjadi redundansi data. Lalu Dalam proses perekapan membutuhkan waktu yang lama karena harus membuka kembali satupersatu arsip perjalanan dinas yang sangat banyak, karena didalam sekali perjalanan dinas Surat pertanggung jawaban (SPJ) yang harus disiapkan oleh pegawai yang melakukan perjalanan dinas meliputi Nota Permintaan perjalanan dinas, Surat Perintah
Dinas (SPT), Surat Perintah Perjalanan Dinas (SPPD), Laporan hasil perjalanan dinas, Surat pernyataan taxi, Surat pernyataan harian, serta kwitansi perhitungan biaya seluruh biaya perjalanan dinas yang digunakan yang terdiri dari Uang harian, penginapan, serta biaya transportasi.

Berdasarkan latar belakang diatas, Tim peneliti menganggap Universitas Terbuka perlu mengembangkan sebuah aplikasi berbasis website agar dapat menjadi sistem informasi bagi pegawai untuk membuat surat tugas dan SPPD di lingkungan Universitas Terbuka.

\section{Metode Penelitian}

Penelitian ini memiliki 4 tahapan dalam kerangka berfikir. Tahapan awal adalah melakukan pengumpulan data. Pada tahapan ini semua data dikumpulkan selanjutnya dilakukan analisis terhadap data tersebut, tujuannya adalah untuk memperoleh desain informasi yang baik. Setelah proses analisis selasai, kemudian dilakukan tahapan selanjutnya yaitu coding.

Kerangka berfikir dalam penelitian ini dapat dilihat pada Gambar 1, pertama 
melakukan pengumpulan data, selanjutnya data tersebut dilakukan analisis untuk mendapatkan desain informasi yang baik, setelah dianalisis mulai dilakukan coding untuk menjadikanya sebuah aplikasi. Setelah aplikasi jadi proses selanjutnya adalah implentasi dengan cara uji coba aplikasi dengan user terkait. untuk menjadikanya sebuah aplikasi. Setelah aplikasi jadi proses selanjutnya adalah implentasi dengan cara uji coba aplikasi dengan user terkait. Kerangka berfikir dalam penelitian ini dapat dilihat pada Gambar 1, pertama melakukan pengumpulan data, selanjutnya data tersebut dilakukan analisis untuk mendapatkan desain informasi yang baik, setelah dianalisis mulai dilakukan coding untuk menjadikanya sebuah aplikasi. Setelah aplikasi jadi proses selanjutnya adalah implentasi dengan cara uji coba aplikasi dengan user terkait.

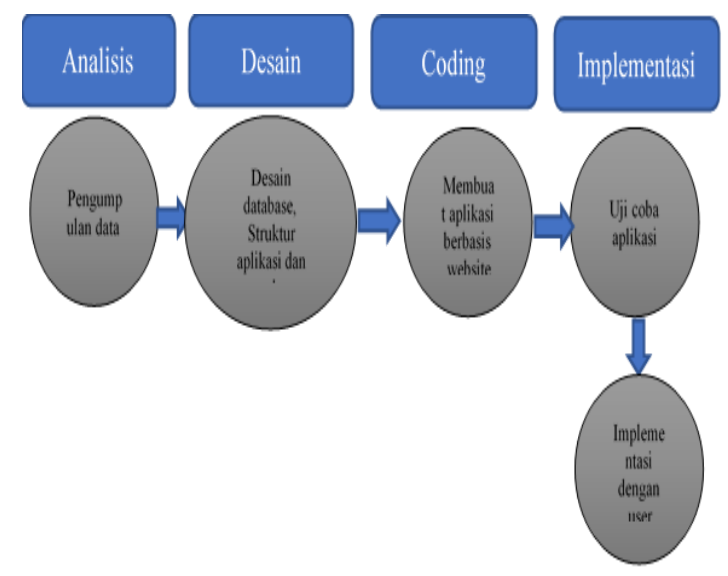

Gambar 1. Kerangka berpikir

\section{1) Jenis Metode Pengembangan Perangkat Lunak}

Metode yang digunakan untuk membangun sistem informasi aplikasi pembuatan surat tugas dan SPPD ini yaitu menggunakan metode Waterfall seperti terlihat pada Gambar 2. Pada metode waterfall terdapat 5 tahapan yang harus dilalui yaitu: Analisis, Desain, Implementasi, Testing dan Pemeliharaan. Pada penelitian ini, metode waterfall tersebut disadur hingga tahap ke-4, dikarenakan program yang dihasilkan hanyalah sebuah prototype, jadi tidak ada maintenance karena belum digunakan.

\section{2) Analisis}

Pada tahap analisis, kami akan menggali informasi melalui wawancara, observasi ke lapangan, serta studi litelatur. Berdasarkan penggalian informasi tersebut maka kami akan menganalisa berbagai kemungkinan baik dan buruknya pembangunan sistem informasi ini, sehingga kami akan menanggulanginya sesuai dengan kebutuhan dilapangan.

\section{3) Desain}

Desain yang dilakukan berasal dari informasi hasil analisis yang telah didapatkan, sehingga kami mampu mendesain sistem informasi atas karya publikasi dosen ini, secara garis besar pada tahapan desain ini terbagi menjadi empat bagian yaitu:
a. Konseptual Sistem
b. Database
c. Alur Kinerja Sistem
d. Tampilan Sistem (Mockup)

\section{4) Impelemntasi}

Implementasi yang dilakukan, dibantu dengan perangkat lunak, perangkat keras, dan jaringan web hosting dan domain. Dengan rincian sebagai berikut:

\section{A. Perangkat lunak}

a) Framework CodeIgniter

Dalam pengembangan aplikasi ini menggunakan Bahasa pemrograman PHP (Hypertext Preprocessor) dan memilih framework Codeigniter sebagai Framework untuk membuat aplikasi menggunakan Bahasa pemrograman PHP. PHP adalah kependekan dari Hypertext Preprocessor atau Profesional Homepage, yaitu sebuah bahasa scripting yang dieksekusi di sisi server (Server-side Scripting Language). Dalam pengertian sederhana, server menerjemahkan script program, setelah itu hasilnya akan dikirimkan kepada client yang melakukan permintaan[2] .

Framework yang dalam Bahasa Indonesia diartikan sebagai "kerangka kerja" adalah kumpulan dari fungsifungsi/prosedur-prosedur dan class-class untuk tujuan tertentu yang sudah siap digunakan untuk mempermudah dan mempercepat pekerjaan seorang programer, tanpa harus membuat fungsi atau class dari awal[3] . 
CodeIgniter adalah sebuah web application network yang bersifat open source yang digunakan untuk membangun aplikasi php dinamis. CodeIgniter menjadi sebuah framework PHP dengan model MVC (Model, View, Controller) dengan tujuan membangun website dinamis menggunakan PHP yang dapat mempercepat pengembang untuk membuat sebuah aplikasi web. CodeIgniter selain ringan dan cepat, juga memiliki dokumentasi yang super lengkap disertai dengan contoh implementasi kodenya. Salah satu alasan kuat mengapa banyak orang memilih CodeIgniter banyak orang memilih CodeIgniter karena dokumentasinya yang lengkap[4].

CodeIgniter dikembangkan pada tahun 2006 oleh Rick Ellis untuk pertama kalinya. Logo api yang menyala membuat CodeIgniter dengan cepat "membakar" semangat para web developer untuk mengembangkan web dinamis dengan cepat dan mudah menggunakan framework PHP yang satu ini.

\section{b) MySQL}

MySQL merupakan perangkat lunak sistem manajemen basis data SQL (database management system) atau DBMS yang multialur, multipengguna, dengan sekitar 100 juta instalasi di seluruh dunia[5]. MySQL AB membuat MySQL tersedia sebagai perangkat lunak gratis di bawah lisensi GNU General Public License (GPL), tetapi mereka juga menjual di bawah lisensi komersial untuk kasus-kasus di mana penggunaannya tidak cocok dengan penggunaan GPL. MySQL tidak hanya dibatasi oleh pengguna perseorangan atau perusahaan kecil, namun perusahaan-perusahaan besar seperti Yahoo!, Alcatel-Lucent, Google, Nokia, Youtube, Wordpress dan Facebook juga merupakan pengguna MySQL[6]. Tidak sama dengan proyek-proyek seperti Apache, di mana perangkat lunak dikembangkan oleh komunitas umum, dan hak cipta untuk kode sumber dimiliki oleh penulisnya masingmasing, MySQL dimiliki dan disponsori oleh sebuah perusahaan komersial Swedia MySQL AB, di mana memegang hak cipta hampir atas semua kode sumbernya. Kedua orang Swedia dan satu orang Finlandia yang mendirikan MySQL AB adalah: David
Axmark, Allan Larsson, dan Michael "Monty" Widenius[7].

\section{c) XAMPP}

XAMPP merupakan sebuah perangkat lunak bebas yang mendukung banyak sistem operasi. XAMPP merupakan kompilasi dari beberapa program. Fungsinya adalah sebagai server yang berdiri sendiri (localhost), yang terdiri atas program Apache HTTP Server, MySQL database, dan penerjemah bahasa yang ditulis dengan bahasa pemrograman PHP dan Perl. XAMPP merupakan singkatan dari $X$ (empat sistem operasi apapun), Apache, MySQL, PHP dan Perl. Program ini tersedia dalam GNU General Public License dan bebas. XAMPP merupakan web server yang mudah digunakan yang dapat melayani tampilan halaman web yang dinamis[8].

\section{B. Perangkat Keras}

Perangkat keras yang digunakan adalah PC/ Laptop dengan spesifikasi Core i5, Ram $4 \mathrm{~Gb}$ HDD 500 GB.

\section{5) Testing}

Testing dilakukan untuk mengetahui bug yang terdapat pada sistem, metode testing yang dapat digunakan yaitu metode black box testing ataupun white box testing, untuk mengetahui kinerja dan kualitas dari sistem yang dibangun.

\section{Hasil dan Pembahasan}

Setelah melakukan analisa sesuai dengan kebutuhan maka didapatkan beberapa hasil yaitu rancangan struktur sistem, rancangan database, dan rancangan Mockup tampilan aplikasi. Semua rancangan dapat dilihat pada berikut ini :

\section{1) Struktur Sistem}

Setelah melakukan analisis kebutuhan aplikasi maka dibuatlah sebuah struktur sistem dengan rancangan sebagai berikut: 


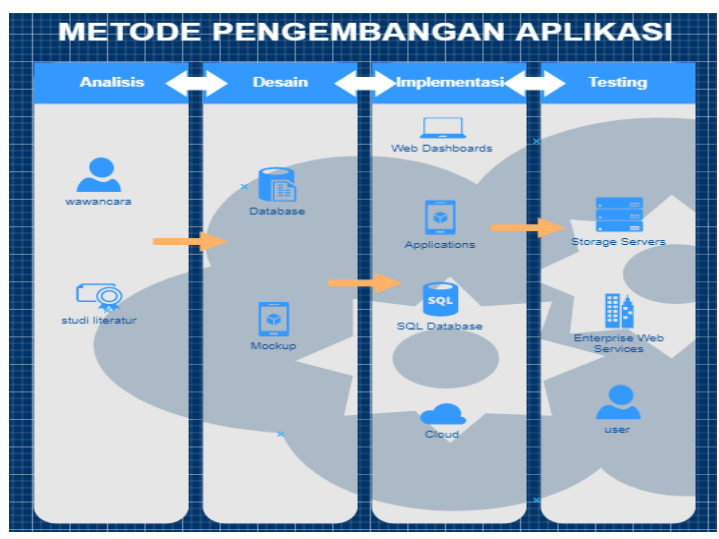

Gambar 3. metode Pengembangan Aplikasi

2) Struktur Database

Database yang digunakan adalah MySql dengan ketentuan tabel sebagai berikut :

\begin{tabular}{|l|lll|}
\hline & $\#$ & Name & Type \\
$\square$ & 1 & id & int(150) \\
$\square$ & 2 & nama_lengkap & varchar(200) \\
$\square$ & 3 & nama_orchar(200) & varchar \\
$\square$ & 4 & password & varchar(200) \\
$\square$ & 5 & email & varchar(200) \\
$\square$ & 6 & level & varchar(200) \\
$\square$ & 7 & fakultas & varchar(200) \\
$\square$ & 8 & program_studi & varchar(200) \\
$\square$ & 9 & file & text \\
$\square$ & 11 & type & varchar(50) \\
$\square$ & 12 & tempat_lahir & varchar(50) \\
$\square$ & 13 & tanggal_lahir & date \\
\hline
\end{tabular}

Gambar 4. Struktur database

3) Rancangan Mockup

Setelah membuat rancangan struktur dan database, tahapan se-lanjutnya adalah membuat rancangan halaman user interface dalam bentuk mockup, dengan detail halaman berikut ini :

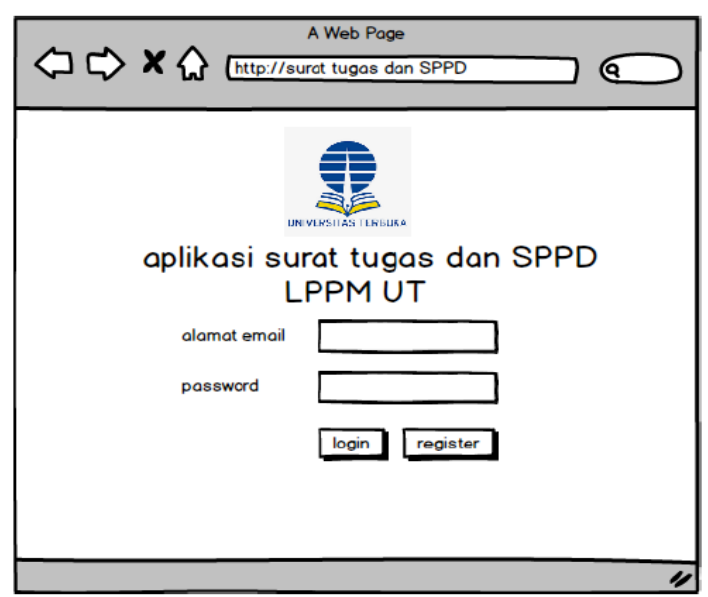

Gambar 5. Mockup login form
Gambar 5 di atas menunjukkan tampilan antarmuka login. Ketika memasuki website maka tampilan inilah yang akan terlihat. Pada tampilan ini menu login dan register. Register digunakan untuk mendaftar, sedeangkan login apabila sudah terdaftar maka bisa langsung masuk ke dashboard.

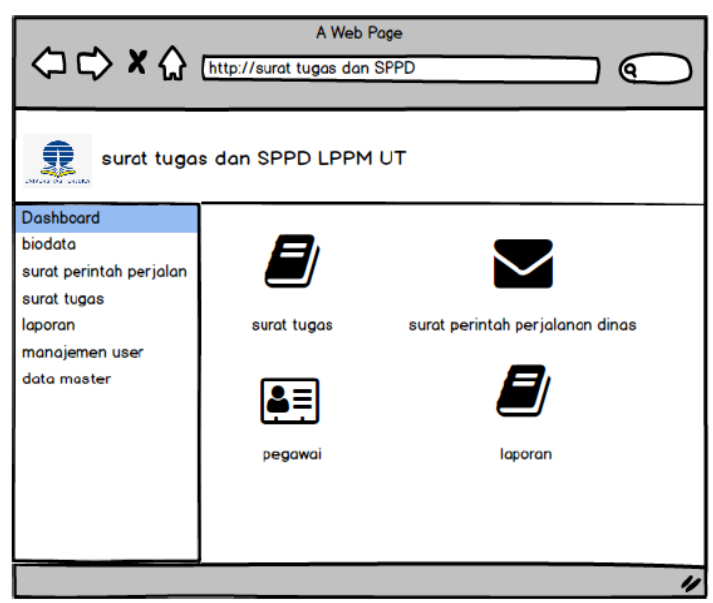

Gambar 6. Mockup dashboard

Gambar 6 menunjukkan tampilan antarmuka dashboard admin. Ketika memasuki akun admin maka tampilan inilah yang akan terlihat. Pada dashboard terdapat menu surat tugas, surat perintah perjalanan dinas, data personal pegawai dan laporan dari perjalan.

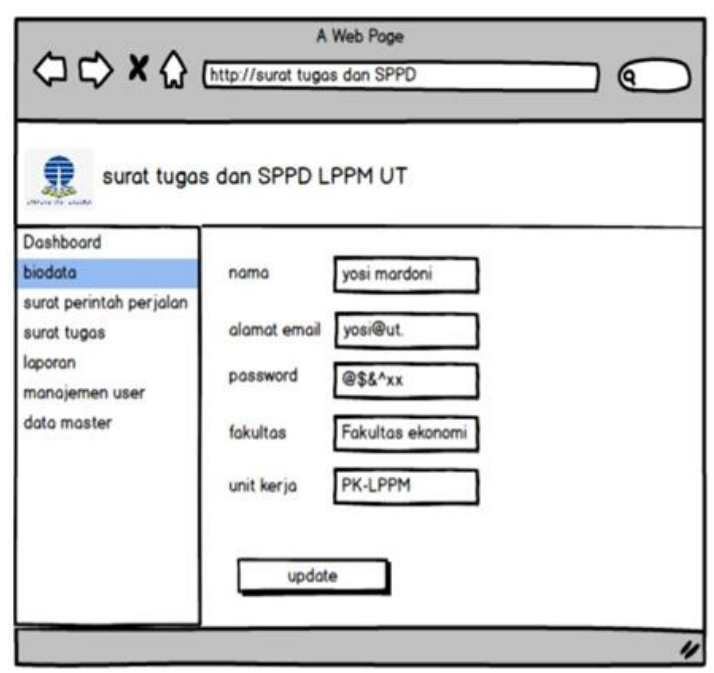

Gambar 7 Mockup biodata

Gambar 7 menunjukkan tampilan biodata. Biodata mencakup nama, email, password, fakultas dan unit kerja dari pegawai. 


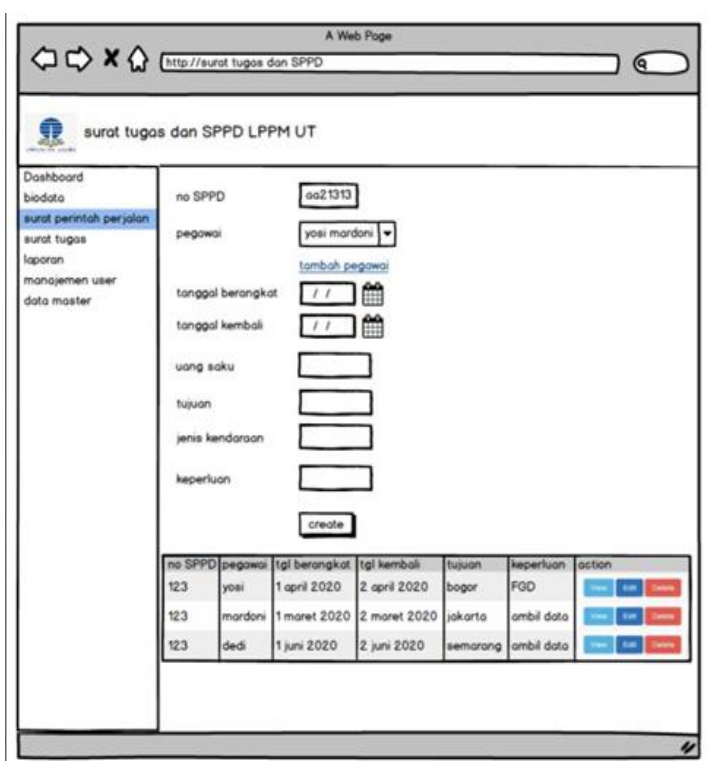

Gambar 8. Mockup Surat Perintah Perjalanan

Gambar 8 menunjukkan tampilan menu surat perintah perjalanan. Pegawai dapat menginput kebutuhan untuk surat perintah perjalanan dinas seperti, tanggal berangkat dan Kembali, dana yang dibutuhkan, tujuan dan keperluan.

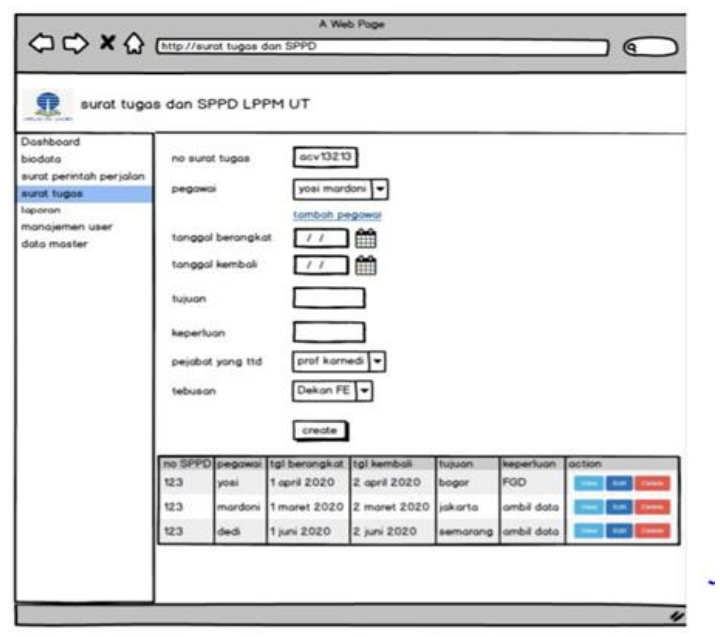

Gambar 9. Mockup Surat Tugas

Gambar 9 menunjukkan tampilan admin surat tugas yang terdiri dari nomor, nama pegawai, tangal berngkat, tanggal Kembali tujuan, keperluan, pejabat yang akan menandatangani dan tembusan.

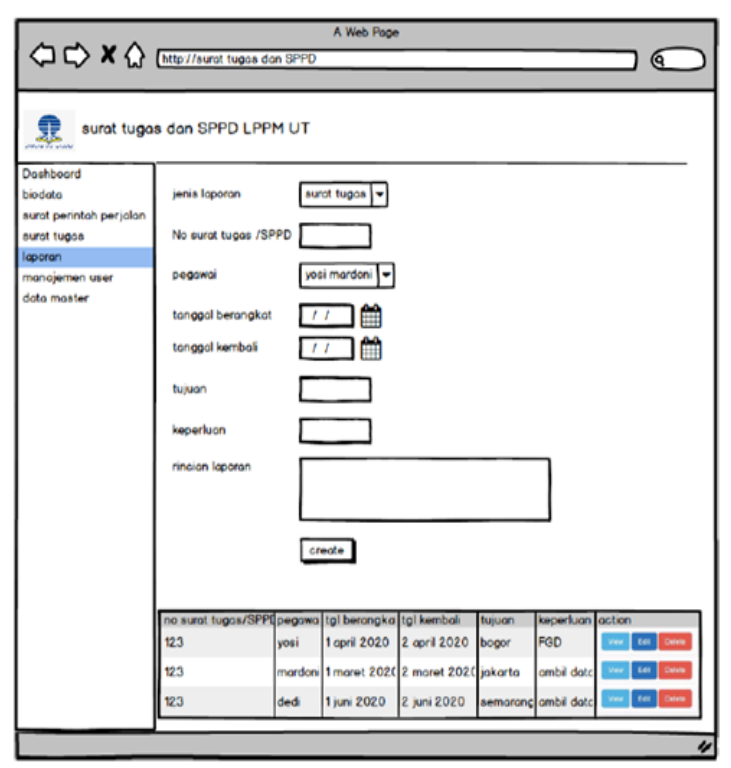

Gambar 10. Mockup laporan

Gambar 10 menunjukkan tampilan laporan perjalanan, yang terdiri dari jenis laporan, nomor surat tugas/SPPD, nama pegawai, tangal berangkat dan Kembali, tujuan keperluan serta rincian laporan.

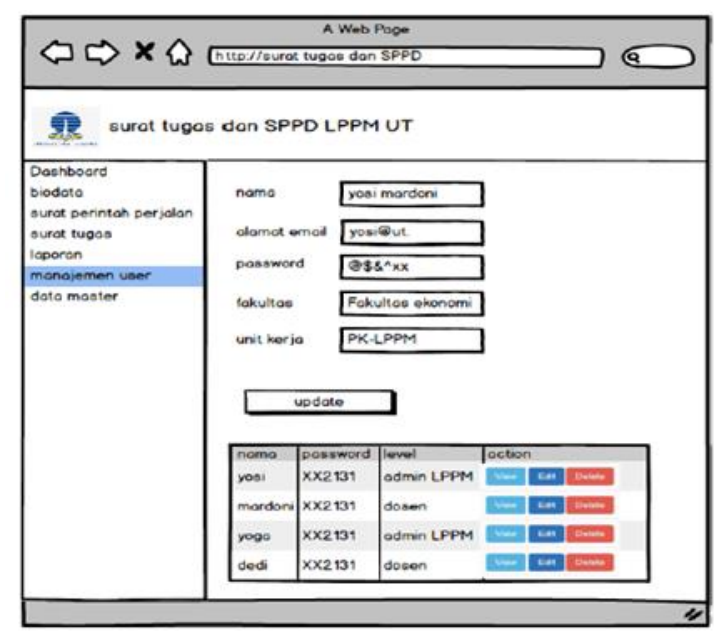

Gambar 11. mockup manajemen user

Sedangkan gambar 11 menunjukkan tampilan manajemen user untuk melakukan update atau perubahan pada data pegawai. Manajemen user terdiri daridari nama, alamat email, password, fakultas dan unit kerja. 


\section{Kesimpulan}

Berdasarakan hasil penelitian yang sudah dilakukan, dapat diambil beberapa kesimpulan sebagai berikut :

1) Pembuatan aplikasi surat tugas sangat membantu karena sebelumnya untuk proses pembuatan surat tugas dan SPPD masih menggunakan form manual.

2) Pada aplikasi ini masih ada beberapa kekurangan karena belum menyesuaikan untuk semua kebutuhan yang ada dilingkungan Universitas Terbuka.

\section{Daftar Pustaka}

[1] Oktaviani, I. and Mulyani, A., 2016. Pengembangan Aplikasi Surat Perintah Perjalanan Dinas. Jurnal Algoritma, 13(1), pp.58-62.

[2] Firman, A., Wowor, H.F. and Najoan, X., 2016. Sistem informasi perpustakaan online berbasis web. Jurnal Teknik Elektro dan Komputer, 5(2), pp.29-36.

[3] Wirdasih, N.W., Ridlwan, H.M. and Wibowo, H., 2019, October. Optimasi Pengurangan Outstanding Purchase Order dengan Sistem Notifikasi Otomatis. In Seminar Nasional Teknik Mesin (Vol. 9, No. 1, pp. 19-26).

[4] Bunga, M.S., Iryanto, I., Puspaningrum, A. and Darmawan, M., 2019, August. Pengembangan Aplikasi Mobile Monitoring Anak Asuh Berbasis Android pada Lembaga Kemanusiaan Kilau Indonesia. In Prosiding Industrial Research Workshop and National Seminar (Vol. 10, No. 1, pp. 97-106).

[5] Munadia, M. and Gani, T.A., 2019. Room Charting berdasarkan Pemetaan Gantt Chart pada Penjadwalan Kuliah Pengganti/Tambahan di Fakultas Teknik Universitas Syiah Kuala. Jurnal Karya Ilmiah Teknik Elektro, 4(4).

[6] Allen G. Tailor. 2003. SQL For Dummies, 5th Edition. Wiley Publishing, Inc

[7] Saputra, A. 2012. Manajemen basis data mysql pada situs ftp lapan bandung. Berita Dirgantara (Vol.13, No.4, pp. 155-162).

[8] Palit, R.V., Rindengan, Y.D. and Lumenta, A.S., 2015. Rancangan Sistem Informasi Keuangan Gereja Berbasis Web Di Jemaat GMIM Bukit Moria Malalayang. Jurnal Teknik Elektro dan Komputer, 4(7),pp.1-7 